\title{
THE ATTENDANCE ABOUT SPORT EVENTS OF THE 50+ COHORTS
}

\author{
Hegedüs, Réka - Csóka, László - Törőcsik, Mária
}

\begin{abstract}
The population of Hungary, similar to the European countries, shows an ageing tendency. The life expectancy at birth and after 65 is growing, as a consequence of which the increased years of life can become meaty besides adequate life quality. An important related area is activity and sports. Accordingly, it can become a priority task to involve the older generations into sport consumption and sport tourism. In their study the authors examine the connections between the attitudes toward sports and sport tourism among the Hungarian population with particular regard to the 50-70 years old people. Based on the results of the survey, carried out within the framework of the project EFOP-3.6.2-16-2017-003: "Cooperative Research Network in Economy of Sport, Recreation and Health", focusing on the sport consumption habits of the Hungarian population the sport-attitudes and travels by reason of sport of the elderly cohorts are demonstrated. On this basis proposals, sports and public health programmes and sports tourism projects can be drafted, which could level up the consumption and activities of the elderly to a higher level.
\end{abstract}

Key words: senior marketing, ageing, sport, sport tourism

JEL: M31, Z29, Z30

DOI: $10.33032 /$ acr.2020.10.1.69 


\section{Introduction}

Sport, transforming into a worldwide leisure time movement since the second half of the $19^{\text {th }}$ century (Elias, 1971), has extended the related researches and economic activities as well. With the exception of professional sportsmen, ordinary people do sport and recreational activities in their leisure time - also, these are among the most popular pastimes (Andorka, 2006). It is a question, though, to what extent this activity, usually associated with the youth (Csóka, 2019; Lampek et al., to be published), appears in the daily routine of the elder generations, or in their consumer behaviour. This includes not only the integration of active and regular movement into their lives, or purchases connected to sports (like season tickets to fitness halls, equipment, media contents), but also travels with sport motivations, which is a basic condition for sport tourism. The discipline of sport tourism requires an interdisciplinary approach, due, on the one hand, to trends continuously changing also in this area (Törőcsik - Jakopánecz, 2018, Törőcsik - Csapó, 2018), on the other hand, because of the comprehensive demands of the industry reaching over nations. As regards the consumer demand trends, sport appears as a primary travel motivation, both in its active and passive form, which requires the development of alternative travel goals, tourism types and tourism products (Csapó et al., 2018, 2019, Gonda - Csapó, 2018, Csapó - Törőcsik, 2019). Similarly to senior marketing (Törőcsik, 2016), senior tourism too has gone through a slow but considerable transition in the last decades, during which the senior citizens have become more and more important actors of tourism industries economically, as opposed to former perceptions (Gyulavári - Ásványi, 2019).

Considering the ever growing proportion of the elderly people both in Europe and Hungary, we must pay more and more attention to the increase of years spent in health and also to the quality of life experienced, so that people aged over 50-60 years can spend their old years in as good intellectual and physical condition as possible (United Nations, 2017, Monostori - Gresits, 2018, KSH, 2019).

The focus group of the paper is the generation aged 50-70, as during this period of their lives they experience several psychological, physical and social changes (including the experience of midlife crisis, followed by the change at the age of fifty, then entering old age), all of which result in changes in their attitudes and habits (see among others Frolkis, 1980, Erikson, 1982, Gorman, 1993). These changes can be seen also in the attitude and behaviour concerning sport and travel. The period before, during and after retirement brings about fundamental changes and adaptation constraints in the lives of both the individuals concerned and the people in their direct environment (Giddens, 2003, Turai, 2009, Vargha, 2015). Incomes are decreasing (one must consider how much s/he can spend); the elimination of job and social contacts is starting; the new leisure time is a problem in the beginning 
or permanently (what to do with it); and the loss of the respect of the younger generation for their skills and expertise can lead to mental problems like the feeling of being redundant or the decay in the physical condition.

The inclusion of the elder generations into sport tourism is a new challenge and market for experts also because Hungary lags behind the European average as regards the sport activities of the population (Ács et al., 2011, Global age-watch index, 2015, Lampek, 2015, European Union, 2017, Eurobarometer, 2018), and so the alleviation of the generational problems can also be approached from the direction of passive sport opportunities, in addition to the active ones.

The paper is focused on leisure time sport tourists, whose motivation can be of push character (Hinch - Higham, 2001), in which case their main motivation is the desire to get away from ordinary days, belonging (to a community), cherishing friendships and the creation of the chance of doing something that they would not do otherwise. The research question of the authors is the attitude of the generation aged 50-70 to sports, sport activities and disciplines, and how these attitudes and interests, or the reason for not doing any sport influence travels with active or passive sport motivation.

\section{Material and methods}

In May-June 2018, a direct questioning of 2,000 people was done in order to examine the behaviour and attitude of the Hungarian population concerning several issues related to the consumption of sports. The questioning was representative of the Hungarian population aged 15-74 as regards gender, age groups (10 year intervals) and the region of the place of residence. The objective of the quantitative survey was to get a valid image of the sport consumption habits of the Hungarian population. As regards sport consumption, special attention was paid in the questionnaire to the issue of sport-motivated consumptions and travels, some findings of which are presented in this paper. The processing and analysis of the results was done with IBM SPSS Statistics 24 and Microsoft Excel 2013 softwares. This paper is about the frequency analysis of questions related to sport consumption, a demography background analysis by gender and generations - with special regard to those aged 50-70 ( $\mathrm{n}=680$ persons), and a comparison to other sport consumption categories. During this a Chi-Square test was made to detect if there are statistically justifiable, significant differences in the sport-motivated travels in the responses of the groups created by generations, and in responses to questions concerning sport consumption categories - at 5\% significant threshold value (in connection with this, in all of the figures or in their contexts 'p' value is indicated). As regards categories of sport 
consumption, the following topics were analysed: active participation, consumption of sport events as experience, consumption of sport-related products and services, and the issue of no sport.

Looking at generations, respondents were divided into age groups with a classic cohort methodology (Pál et al., 2017) - young generation (up to 29 years of age), middle generation (aged 30-59) and seniors (60+) (Smith - Clurman, 1997) in a comparison to our focus group, those aged 50-70. In some cases this group was divided into two groups: those aged in their fifties and in their sixties.

\section{Results}

An important issue when examining attitudes concerning sport activities and sport consumption is the opinion and feelings of the consumer group surveyed when they hear the expressions 'sport', 'sport activity'. Considering the total sample of 2,000 people it can be said (Csóka - Törőcsik, 2018) that the expression 'sport' evokes positive emotions from respondents on the whole and basically - in each generation, but the intensity of positive attitude somewhat lessens with the aging of the respondents. (We asked evaluation along a ten-point Likert scale where value 1 meant that the expression evoked very negative feelings in the respondent, while 10 meant very positive ones.) Members of the senior generation have negative feelings by more than $20 \%$ than the young have and show a $10 \%$ worse opinion than those of the middle-aged generation. The gradual worsening can also be detected in the tenyear intervals as well. The opinions of respondents aged 50-70 shows that more than $50 \%$ of them have a more positive opinion about the expression (values 7-10 on the scale), but it must also be mentioned that many of them agreed with the statement saying that "sport is for young people" (measured with a five-point Likert scale where 1 means a total disagreement and 5 means full agreement; $\mathrm{p}=0.000<0.05$ ). More than $13 \%$ of them fully agree, and in comparison with the complete respondent base $10 \%$ more are inclined towards agreement. It can also be said of the respective age group that the proportion of persons interested in sports $(35.7 \%$, considering responses at $7-10$ value) and indifferent ones (37.1\%; values $1-4)$ are by and large the same. On the whole, slightly more than half of the group are rather not interested in sport (disciplines and doing sport) (at a ten-point Likert scale: 1 - not interested at all, 10 - very much interested), and there is no significant difference related to the age, between those in their fifties and sixties. The authors thus think that interest in sports come more from attitude differences than from the age of respondents in the 50-70 age group, as opposed to the three-generational division where the youth are definitely more interested in sport. 
The picture is further nuanced if the sport habits of this same generation are taken into consideration too: $68.2 \%$ of them do not do any sport and another $22 \%$ used to do sport but have already stopped it. Unfortunately, only 67 persons of this age group are active in sport now. The reasons for non-sport - by the declarations of respondents - are health $(32 \%)$, age $(31 \%)$ and lack of time $(30.5 \%)$ that were mentioned (Figure 1). As regards health reasons and age, significant differences ( $\mathrm{p}=0.013<0.05$ and $\mathrm{p}=0.000<0.05$, respectively) can be seen between the segment aged 50-59 and the one aged 60-70, not surprisingly "in favour" of the latter. To the opposite, lack of time as an excuse is more frequently mentioned by those in their fifties $(p=0.000<0.05)$. Among those mentioning laziness $(p=0.012<0.05)$ it is those in their fifties who prevail by over $60 \%$. While significant differences can be seen in the three-generational breakdown of the total basis of 2,000 respondents among the generations in both the lack of company and the lack of sport motivation (Csóka - Töröcsik, 2018), this cannot be seen in the age group 50-70 years old; also the two sub-groups are not sharply differentiated by the excuses "no possibility nearby", "cannot afford it" and "do not want to display my body" - these reasons do not even appear in responses in considerable numbers.

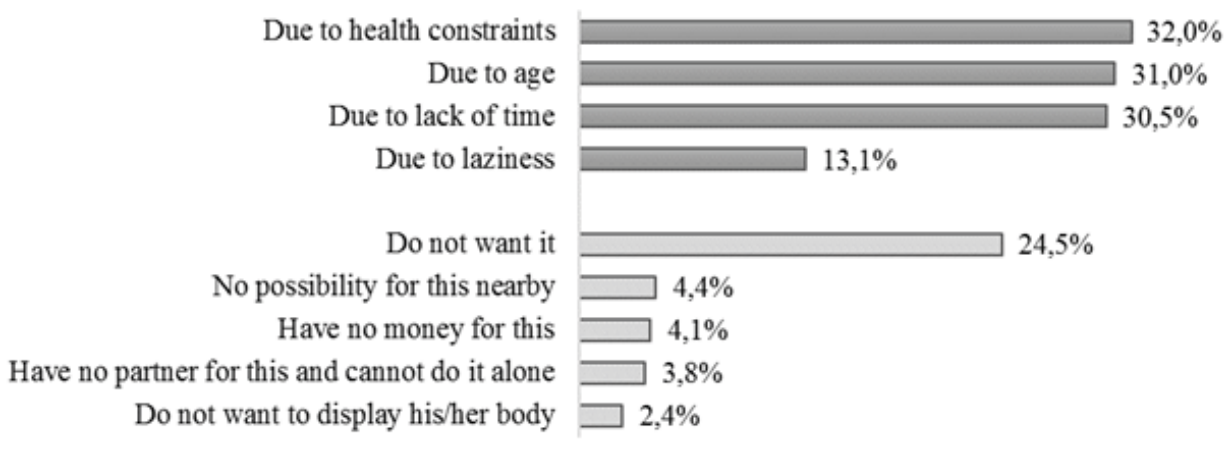

Figure 1: Why do you not do any sport now?

Source: edited by the authors; respondents aged 50-70 not doing any sport, $n=613$, in percentage of mentions. Significant differences that can be statistically justified with a Chi-Square test between the age groups aged 50-59 and 60-70 due to health restrictions $(p=0.013<0.05)$, age $(p=0.000<0.05)$, lack of time $(p=0.000<0.05)$ and laziness $(p=0.012<0.05)$.

As only $9.9 \%$ of the generation aged $50-70$ do sport at some level, it is more useful to turn our attention to other sport motivations of non-sporting respondents: it is worth examining, among other things, general features of sport motivated travels, the domestic or international character of sport motivated travels, and their frequencies and goals. The fact that the larger part of the senior generation is inactive in sport does not mean that they do not have passive interest; they may even have 
sport as a new hobby. When, in connection with this, general sport motivated travels were examined, we found that $92 \%$ of the generation aged 50-70 do not travel, as opposed to $87.2 \%$ of all Hungarians participating in the survey (CSÓKA et al., 2019). Sport activities improve the willingness to do sport at this generation too, as $25 \%$ of those still actively doing sport travel with sport motivations, as opposed to only $13 \%$ travelling with sport motivations among those no longer active in sports; their proportion is still negligible, however, compared to the share of non-travellers. This means that the propaganda and popularisation of sport motivated travels for the seniors should not be approached from the willingness to do sports. Among the excuses for no sport by the respondents in their fifties and sixties it was only the existence or absence of interest in sport that showed a significant difference $(\mathrm{p}=0.000<0.05)$ as regards sport motivated travels - it is evidently the ones interested in sport who more typically travel; the willingness for sport motivated travels was not significantly impacted either by age, health conditions or laziness.

In connection with the sport motivated travels of respondents aged 50-70 we asked whether they had been travelling for sport within Hungary or abroad in the year before the questionnaire survey (2017). The majority (88\%) of those few who do travel with sport motivation had actually travelled for sport in Hungary in the previous year - typically 1-4 times, but some were willing to travel up to 10 times. The number of travels for sport abroad, on the other hand, is negligible, only a few persons indicated their single experience of this kind. The reasons for travels of those few who had travelled in Hungary in the previous year are featured in Figure 2. It reveals that most of them had been spectators or attendants at the respective event.
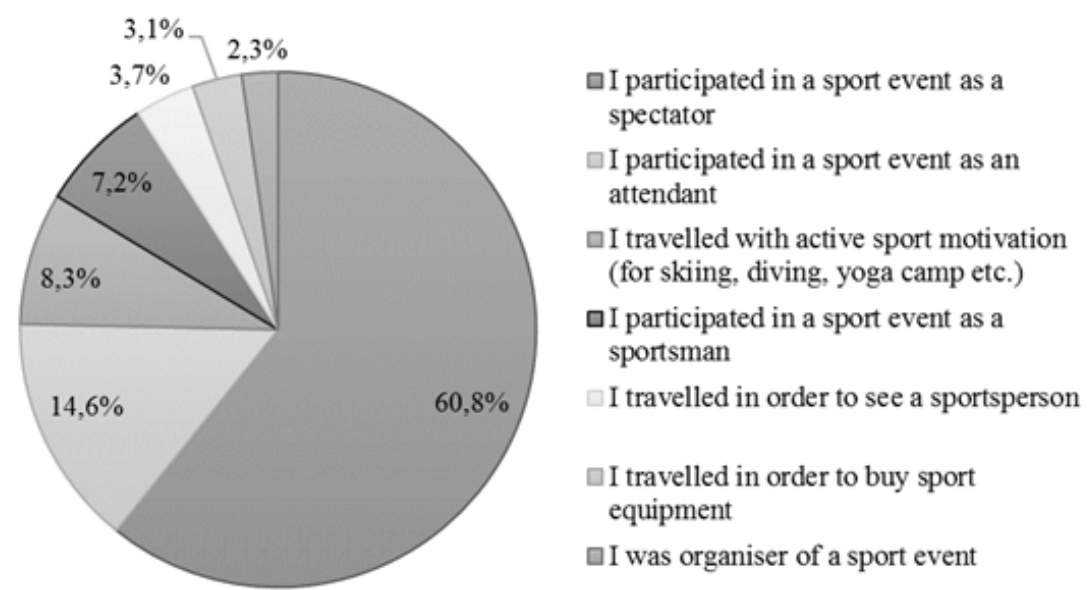

Figure 2: What was the reason for your sport travel in Hungary in the last one year? Source: edited by the authors; those of respondents aged 50-70 who travelled in the previous year, $n=59$ 
As interest in sport in general and in sport disciplines, as well as participation in sport events as spectator has a positive impact on sport motivated travels in this age group, we examined the events of which sports have the strongest impact on moving out. In Figure 3, only sports showing significant differences are displayed, in decreasing percentages of the sport motivated travels. The respondents aged 50-70 are most typically attracted by soccer $(43.4 \%)$, swimming $(37.4 \%)$, handball $(34.6 \%)$, water polo $(31.3 \%)$ and motor sport $(26 \%)$ news and events. Despite the general popularity of these sports in Hungary, the proportion of respondents interested from the examined age group remains below $50 \%$ in each case. The figure reveals that football attracts the largest number of people, and this sport is the main motivator of sport related travels as well $(5.9 \%)$. This is followed by handball with its $34.6 \%$ popularity rate, of which $5.3 \%$ actually travel. Interestingly, swimming grabs the attention or a larger number of people and still it attracts less people to travel than handball does. Sports evoking the least enthusiasm include fitness halls (5.4\%) and e-sports (2.4\%), but the opening up of seniors towards these novelties may be indicated by the fact that some respondents were motivated by these, even though in negligible numbers.

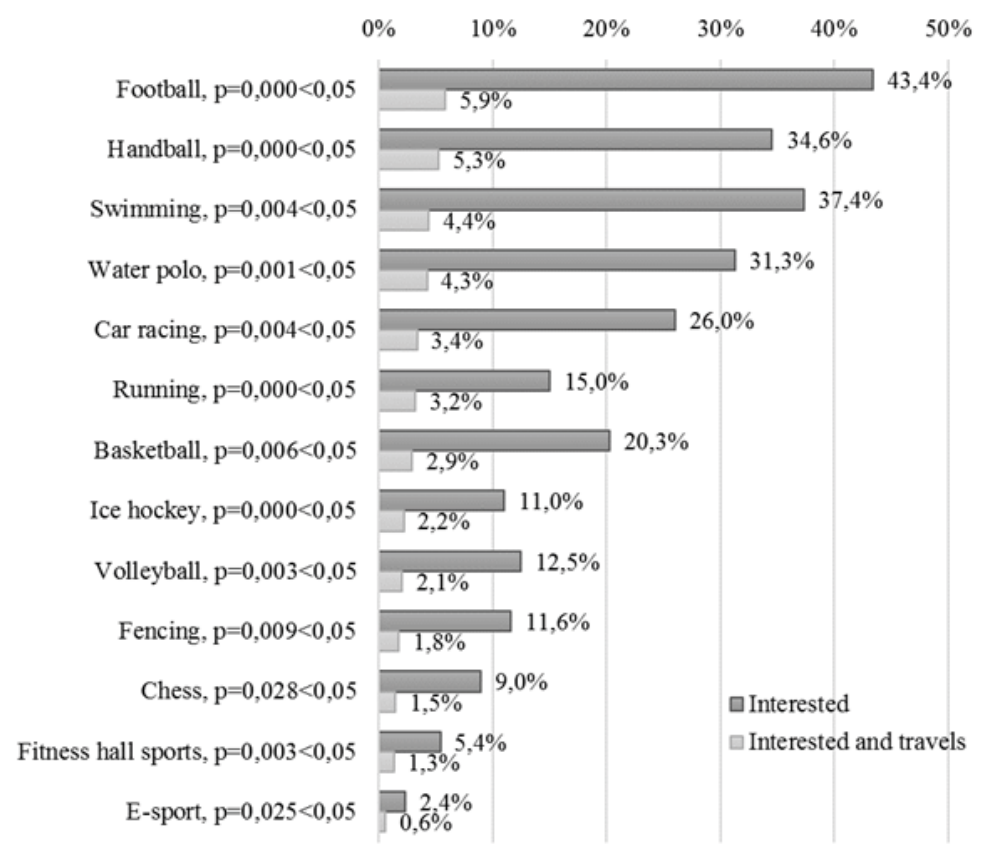

Figure 3: Relationship between sport motivated travel and interest in sport disciplines: "Are you interested in news and events of the following sports/disciplines?" - "Do you travel with sport motivation (doing sport, visiting a sport event)?"

Source: edited by the authors; respondents aged 50-70, $n=680$ 


\section{Conclusions}

An important issue in connection with sport related habits is what feelings people have towards sports in general, if their attitude is positive or negative, as the factors of the attitudes have a strong influence on openness for sport activities and even sport related travels. Looking at the age group of those 50-70 years old we can see that they have positive attitude towards sports on the whole, they do not necessarily associate sports with the youth, only, although a 10 per cent higher share of them agree with the latter statement than in the Hungarian population younger than them.

Despite the fact that according to the self-declarations the majority do not have any medical challenge limiting sport activities, and more than $30 \%$ have overweight, and also somewhat more than $20 \%$ of them have obesity, only a small fraction of the age group are active in sports. Those in their fifties usually neglect sport for lack of time or due to laziness, their ten years older counterparts do so mainly because of their age and the concomitant changes in their health. The generation examined more typically does not require sport and it is not necessarily a problem for them if they have no partner for sport, but it is known from literature that the presence of social motivations has a positive impact on sport habits.

As regards passive sport-related activities, the cohort examined involves almost in the same proportions persons interested and not interested in sport news and events, and this interest is not a function of their age, it comes more typically from different attitudes towards sports. Ninety-two per cent of the generation does not travel with sport purposes; if they still do, it is usually participation in sport events as spectators or attendants. The habit of active sports, on the other hand, has a positive impact on the motivation to travel also at this age group.

Accordingly, the propaganda and popularisation of sport motivated travels for the seniors should not be approached from the willingness to do sports; instead, larger emphasis must be placed on the interest in the respective sports, no matter if these are team or individual competitions. Although the larger part of senior tourism is built on health care, the vitalisation of sport motivated travels still means unused possibilities and markets, as the senior do not completely refrain from these activities. For this purpose, interest in sport must be gradually increased, maybe in an organised form, connected to travels with other motivations, placing an emphasis on building social contacts.

\section{Acknowledgements}

This research was partially supported by the Human Resource Development Operational Programme, grant No.: EFOP-3.6.2-16-2017, Cooperative Research 
Network in Economy of Sport, Recreation and Health and grant No.: EFOP-3.6.116-2016-00004: "Comprehensive improvements to the University of Pécs in order to achieve the smart specialisation".

\section{References}

[1.] Ács P. - Hécz R. - Paár D. - Stocker M. (2011): A fittség (m)értéke. A fizikai inaktivitás nemzetgazdasági terhei Magyarországon. Közgazdasági Szemle, LVIII. évf. 2011. július-augusztus, 689-708. o.

[2.] Andorka R. (2006): Bevezetés a szociológiába. Budapest: Osiris Kiadó.

[3.] Csapó J. - Törőcsik M. (2019): Turizmus és biztonság: a magyar lakosság utazási szokásaihoz köthető, biztonsággal kapcsolatos attitüdök reprezentatív vizsgálata. Turizmus Bulletin, 19: 3 pp. 13-20.

[4.] Csapó J. - Gerdesics V. - Gonda T. - Raffay Z. - Törőcsik M. (2018): Turizmus: a magyar lakosság turizmussal kapcsolatos beállitódása generációs szemléletü vizsgálattal - országosan reprezentativ személyes $(n=2001)$ és online (n=1085) megkérdezés, fókuszcsoportos viták eredményei. Pécs: PTE KTK.

[5.] Csapó J. - Gonda, T. - Raffay Z. (eds.) (2019): Turizmus, fogyasztás, generációk: II. Nemzetközi Turizmus Konferencia: Tanulmánykötet. Pécs: PTE KTK.

[6.] Csapó J. - Törőcsik M. - Nagy Á. (2019): Nemturizmus és életstílus összefüggések. Turisztikai és Vidékfejlesztési Tanulmányok, 4: 5-18.

[7.] Csóka L. (2019): Generational differences in Hungary on sporting habits and on attitudes towards sport - focus on the older generation. In A. Oláh, \& A. Sík (eds.): Art of Ageing - International Conference and Professional Training For the Active Elders. Final program and abstracts (p. 12). Pécs: PTE Egészségtudományi Kar.

[8.] Csóka L. - Törőcsik M. (2018): A magyar sportfogyasztás generációs jellemzői. In R. Resperger (ed.): Demográfiai változások, változó gazdasági kihivások Nemzetközi Tudományos Konferencia. Tanulmánykötet. (pp. 431443.) Sopron: Soproni Egyetem Kiadó.

[9.] Csóka L. - Törőcsik M. (2018): Sportfogyasztás. A magyar lakosság sportolással, sportfogyasztással kapcsolatos magatartása, beállitódása-országosan reprezentativ személyes megkérdezés eredményei. Kézirat. Pécs: PTE KTK. 
[10.] Csóka L. - Gerdesics V. - Törőcsik M. (2019): Sports tourism and sports tourists: The Hungarian characteristics of sports related travels. Journal of Tourism Challenges and Trends, 47-66.

[11.] Elias, N. (1971): The Genesis of Sport as a Socilogical Problem. In E. Dunning (ed.): The Sociology of Sport. A Selection of Readings. London: Frans Cass and Co.

[12.] Erikson, E. (1982): The life cycle completed. New York: Norton.

[13.] Eurobarometer (2018): Sport and physical activity. Downloaded on 20 February 2020 from http://ec.europa.eu/commfrontoffice/ publicopinion/ebs_472_en.pdf

[14.] European Union (2017): The 2018 Ageing Report. Underlying Assumptions \& Projection Methodologies. European Economy Institutional Paper 065.

[15.] Frolkis, V. (1980): Az öregedés és az életkor. Budapest: Gondolat Kiadó.

[16.] Giddens, A. (2003): Szociológia. Budapest: Osiris.

[17.] Global age-watch index (2015): Insight report, summary and methodology. HelpAge International. Downloaded on 20 February 2020 from http://www. helpage.org/global-agewatch/reports/global-agewatch-index-2015-insightreportsummary-and-methodology/

[18.] Gonda T. - Csapó, J. (2018): The Role of Active Tourism and Physical Activity in the Travel Habits of the Hungarian Population. The Results of a Representative Survey. Journal of Tourism Challenges and Trends, 12: 1 (December) pp. 25-47.

[19.] Gorman, M. (1993): Mid-life Transition in Men and Women. In R. Wicks, \& R. Parsons (eds.), Clinical Handbook of Pastoral Counseling. (pp. 297312.) New York: Paulist Press.

[20.] Gyulavári T. - Ásványi, K. (2019): Szeniorturizmus. In A., Irimiás, M., Jászberényi, \& G., Michalkó (eds.): A turisztikai termékek innovativ fejlesztése (pp. 126-136.) Budapest: Akadémiai Kiadó.

[21.] Hegedüs R. - Törőcsik M. - Németh P. (2018): Ageing Magyarországon Generációs eltérések a korérzékelésben. In: Resperger, R. (ed.): Demográfiai Változások, Változó Gazdasági Kibivások Nemzetközi Tudományos Konferencia. Sopron, 2018. november 8. - Tanulmánykötet. Soproni Egyetem. pp. 403-420.

[22.] Hinch, T. - Higham, J. (2001): Sport tourism: a framework for research. International Journal of Tourism Research, 3, 45-58. 
[23.] KSH (2019): Magyarország népességének száma nemek és életkor szerint, 2019. január 1. Interaktiv korfa. Downloaded on 20 February 2020 from https:// www.ksh.hu/interaktiv/korfak/orszag.html

[24.] Lampek K. (2015): Az aktív időskor és a társadalom. In K. Lampek, \& E. Rétsági (eds.): Egészséges idösödés: Az egészségfejlesztés lehetöségei idös korban (pp. 8-27.) Pécs: PTE.

[25.] Lampek K. - Csóka L. - Hegedüs R. - Zrínyi M. - Törőcsik M. (in press): Sports activities of 60 above Hungarian elderly - explaining and predicting impact of exercise on health. BMC Public Health.

[26.] Monostori J. - Gresits, G. (2018): Idősödés. In J., Monostori, P., Öri, \& Z., Spéder (eds.): Demográfiai portré 2018 (pp. 127-145.) Budapest: KSH NKI.

[27.] Pál E. - Törőcsik M. - Jakopánecz E. (2017): Eltérő életkori lehatárolásokból adódó generációk értékeinek empirikus vizsgálata. Marketing és Menedzsment 51: 3 pp. 18-32. , 15 p.

[28.] Smith, W.-Clurman, A. (1997): Rocking the Ages. New York: HarperBusiness.

[29.] Törőcsik M. (2016): Fogyasztói magatartás. Insight, trendek, vásárlók. Budapest: Akadémiai Kiadó.

[30.] Törőcsik M. - Csapó J. (2018): Fogyasztói trendek hatása a turizmusra. In J., Csapó, V., Gerdesics, \& M., Törőcsik (eds.): Generációk a turizmusban. I. Nemzetközi Turizmusmarketing Konferencia: Tanulmánykötet (pp. 8-22.).Pécs: PTE KTK.

[31.] Törőcsik M. - Jakopánecz E. (2018): Sportfogyasztásra ható megatrendek. Trendtanulmány a sport területét befolyásoló fogyasztói magatartásváltozásokról. Pécs: PTE KTK.

[32.] Törőcsik M. - Németh P. (2018): Ageing. A magyar lakosság korral, öregedéssel kapcsolatos beállitódása generációs szemléletü vizsgálattal. Pécs: PTE KTK.

[33.] Turai T. (2009): Öregek társadalomnéprajzi vizsgálata. Doktori értekezlet. Budapest: Eötvös Loránd Tudományegyetem Bölcsészettudományi Kar.

[34.] United Nations (2017): Department of Economic and Social Affairs, Population Division: World Population Prospects: The 2017 Revision, Key Findings and Advance Tables. New York: United Nations.

[35.] Vargha L. (2015): A társadalmi öregedés hagyományos és alternatív indikátorai. Demográfia, 58. évf. (1. szám), pp. 57-78. 


\section{Authors:}

Hegedüs, Réka

$\mathrm{PhD}$ student

University of Pecs Faculty of Business and Economics

Department of Marketing and Tourism

hegedus.reka@ktk.pte.hu

Csóka, László

PhD student

University of Pecs Faculty of Business and Economics

Department of Marketing and Tourism

csoka.laszlo@ktk.pte.hu

Dr. Törőcsik, Mária

professor

University of Pecs Faculty of Business and Economics

Department of Marketing and Tourism

torocsik.maria@ktk.pte.hu 